\title{
The response of Escherichia coli to ciprofloxacin and norfloxacin
}

\author{
T. S. J. ELLIOTT*, A. SHELTON and D. GREENWOOD
}

Department of Microbiology and PHLS Laboratory, University Hospital, Queen's Medical Centre, Nottingham NG7 $2 U H$

\begin{abstract}
Summary. The action of ciprofloxacin and norfloxacin on two strains of Escherichia coli was studied by diverse methods including electronmicroscopy, viable counting and continuous turbidimetric monitoring. During the first few hours of exposure to inhibitory concentrations of the drugs, the opacity of bacterial cultures continued to increase for a period that was inversely proportional to the drug concentration. This change corresponded to the appearance of filamentous bacteria, swollen forms and some lysis. There was subsequently a gradual drop in opacity during which extensive lysis occurred. As judged by viable counts of bacteria washed free of drug, cell death occurred within $30 \mathrm{~min}$ of first exposure to the drugs and continued over a 3-h period. Ultrastructure studies demonstrated that lysis was preceded by the formation of vacuoles, predominantly at the poles of the cells. At these sites, breaks in the cell walls eventually occurred, resulting in extrusion of the cytoplasmic contents.
\end{abstract}

\section{Introduction}

Ciprofloxacin and norfloxacin are fluorinated, piperazine-substituted quinolones related to nalidixic acid; ciprofloxacin differs from norfloxacin in having an $\mathrm{N}$-cyclopropyl group rather than an $\mathrm{N}$ ethyl substituent on the quinolone-ring system. This modification appears to render ciprofloxacin more active than norfloxacin, but both compounds exhibit impressive bactericidal activity against a wide spectrum of bacteria including most Enterobacteriaceae (Newsom et al., 1982; Wise et al., 1983). Exposure to inhibitory concentrations of ciprofloxacin and norfloxacin causes filamentation of bacteria (Greenwood and O'Grady, 1978; Smith, 1984) and a recent ultrastructure study has revealed that a similar response to nalidixic acid is accompanied by polar vacuolation of affected cells (Dougherty and Saukkonen, 1985). Bacteria that continue to elongate in the presence of these agents are thought to be non-viable (Smith, 1984).

We have attempted to elucidate further the response of Escherichia coli to ciprofloxacin and norfloxacin by parallel observations with the techniques of scanning and transmission electronmicroscopy, viable counting and continuous turbidimetric monitoring.

Received 18 Apr. 1986; accepted 6 Jun. 1986.

*Present address: Department of Microbiology, Medical School, Framlington Place, Newcastle upon Tyne NE2 4HH.

\section{Materials and Methods}

\section{Antibacterial agents}

Ciprofloxacin was provided by Bayer UK Ltd; suitable concentrations were prepared in sterile distilled water. Norfloxacin was provided by Merck, Sharp and Dohme Ltd; appropriate concentrations were prepared by dissolving weighed powder in $\leqslant 1 \mathrm{ml}$ of $0.5 \mathrm{~N} \mathrm{NaOH}$ and diluting further with sterile distilled water.

\section{Bacterial strains}

The nalidixic acid-sensitive strain ECSA 1 of $E$. coli and the nalidixic acid-resistant strain $23 \mathrm{~T}$ of $E$. coli were examined. Both strains have been used in previous investigations of quinolones (Greenwood et al., 1984a,b).

\section{Antibiotic titrations}

Serial twofold dilutions of the antibacterial agents were prepared in 1-ml volumes of 'complete' broth (Greenwood and O'Grady, 1973). Tubes were inoculated with an equal volume of broth cultures of bacteria in the logarithmic phase of growth, to achieve an inoculum of $c .10^{5} \mathrm{cfu} /$ $\mathrm{ml}$. The minimum inhibitory concentration (MIC) was taken as the lowest concentration of antibiotic that inhibited growth after incubation for $16 \mathrm{~h}$. Minimum bactericidal concentrations (MBCs) were subsequently determined by subculture of tubes above the MIC; the $\mathrm{MBC}$ was taken as the concentration causing a 1000 -fold reduction in the original inoculum $(99 \cdot 9 \%$ kill).

\section{Turbidimetric studies}

Volumes $(20 \mathrm{ml})$ of complete broth were inoculated 
with bacteria from overnight broth cultures to achieve an inoculum of $c .5 \times 10^{5}$ bacteria $/ \mathrm{ml}$. The cultures were incubated in a 12-channel continuous opacity monitoring device (Mackintosh et al., 1973). Appropriate concentrations of antibacterial agent were added to the cultures when growth had raised the opacity to $30 \%$ of maximum, equivalent to a viable count of $c .10^{8}$ bacteria $/ \mathrm{ml}$.

\section{Viable counts}

At various time intervals, $0 \cdot 1-\mathrm{ml}$ samples were taken from broth cultures in the turbidimetric experiments. After washing the bacteria three times in fresh broth, serial tenfold dilutions were made in complete medium. Duplicate $0 \cdot 1-\mathrm{ml}$ portions of the dilutions were plated on to $5 \%$ blood agar plates, and the number of colonies was counted after incubation at $37^{\circ} \mathrm{C}$ for $16 \mathrm{~h}$.

\section{Electronmicroscopy}

From the broth cultures in the turbidimetric experiments, samples were taken at various time intervals for processing for scanning electronmicroscopy and thinsection transmission electronmicroscopy.

\section{Thin sectioning}

The bacteria were fixed for $6-8 \mathrm{~h}$ at room temperature in glutaraldehyde $5 \%$ in $0.05 \mathrm{M}$ sodium cacodylate $(p \mathrm{H}$ $7 \cdot 2$ ) containing $10 \mathrm{~mm} \mathrm{MgSO}_{4}$. The samples were embedded in agarose $2 \%$ and processed as previously described (Elliott and Greenwood, 1983). Sections were cut with an ultramicrotome (Ultratome III, LKB Instruments) and mounted on formvar and carbon-coated grids. Sections were stained for $1 \mathrm{~min}$ in the dark with uranyl acetate $1 \%$, followed by a wash with water and then lead citrate for $20 \mathrm{~s}$. The specimens were examined in a Jeol $100 \mathrm{C}$ electronmicroscope at an accelerating voltage $100 \mathrm{Kv}$.

\section{Scanning electronmicroscopy}

Samples were fixed in glutaraldehyde $5 \%$ in $0.05 \mathrm{M}$ sodium cacodylate containing $10 \mathrm{mM} \mathrm{MgSO}_{4}$ for $1 \mathrm{~h}$ and then dehydrated in alcohol followed by acetone. The bacteria were critical-point dried (Polaron Equipment) and gold coated for $2 \mathrm{~min}$ in a sputter coater (E. M. Scope). Electron micrographs were obtained by use of the scanning facility of the Jeol $100 \mathrm{C}$ electronmicroscope.

\section{Results}

\section{Titrations}

Ciprofloxacin was more active than norfloxacin against the nalidixic acid-sensitive strain of $E$. coli but both compounds exhibited similar reduced activity against the nalidixic acid-resistant strain (table).
Table. Susceptibilities of two strains of $E$. coli to norfloxacin and ciprofloxacin

\begin{tabular}{|c|c|c|c|c|}
\hline \multirow[t]{2}{*}{ Bacterial strain } & \multicolumn{2}{|c|}{$\begin{array}{l}\text { Ciprofloxa- } \\
\operatorname{cin}(\mu \mathrm{g} / \mathrm{ml})\end{array}$} & \multicolumn{2}{|c|}{$\begin{array}{l}\text { Norfloxacin } \\
\qquad(\mu \mathrm{g} / \mathrm{ml})\end{array}$} \\
\hline & MIC & MBC & MIC & $\mathrm{MBC}$ \\
\hline $\begin{array}{l}\text { E. coli ECSA 1 } \\
\text { (nalidixic acid } \\
\text { sensitive) }\end{array}$ & 0.06 & $0 \cdot 12$ & 0.25 & 0.5 \\
\hline $\begin{array}{l}\text { E. coli } 23 \mathrm{~T} \\
\text { (nalidixic acid } \\
\text { resistant) }\end{array}$ & $16 \cdot 0$ & $16 \cdot 0$ & $16 \cdot 0$ & $16 \cdot 0$ \\
\hline
\end{tabular}

\section{Turbidimetric studies}

Continuous opacity records of the nalidixic acidsensitive strain ECSA 1 exposed to ciprofloxacin and norfloxacin are shown (fig.1). On addition of the antibacterial agents to the cultures, growth followed the normal curve for a short period which decreased inversely with the drug concentration. There was a subsequent prolonged fall in opacity at antibiotic concentrations $\geqslant 0.01 \mu \mathrm{g} / \mathrm{ml}$. The overall response was reproducible, but the degree of rise and subsequent fall in opacity varied somewhat between experiments.

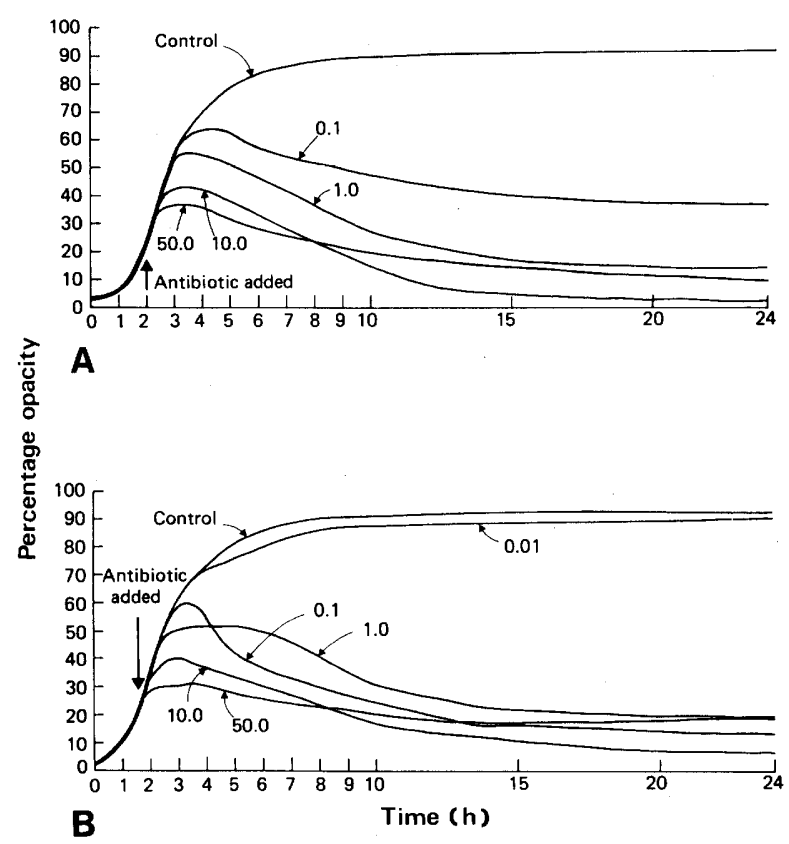

Fig. 1. Continuous opacity records of E. coli strain ECSA 1 exposed to various concentrations of: ciprofloxacin, A; norfloxacin, B. Antibiotics $(\mu \mathrm{g} / \mathrm{ml})$ were added at arrow. 


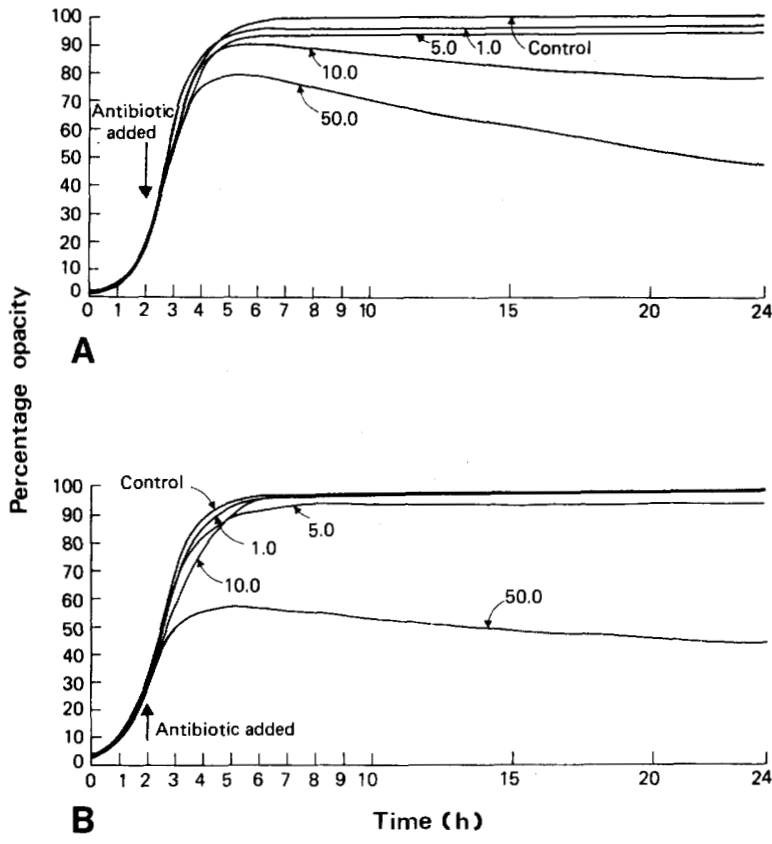

Fig. 2. Continuous opacity records of E. coli strain 23T exposed to various concentrations of: ciprofloxacin, A; norfloxacin, B. Antibiotics $(\mu \mathrm{g} / \mathrm{ml})$ were added at arrow.

The response of the nalidixic acid-resistant strain $23 \mathrm{~T}$ of $E$. coli was different in that it exhibited a reduced response to both ciprofloxacin and norfloxacin; a fall in turbidity was produced only at concentrations $\geqslant 50 \mu \mathrm{g} / \mathrm{ml}$ (fig. 2).

\section{Morphological studies}

The structure of both strains of $E$. coli as observed by thin-section and scanning electronmicroscopy was similar. The bacterial cells had smooth outer membranes, bilayered cell walls and cytoplasm containing evenly dispersed ribosomes and nuclear material (fig. 3).

After exposure of the nalidixic acid-sensitive strain of $E$. coli to either ciprofloxacin or norfloxacin at concentrations between 1 and $50 \mu \mathrm{g} / \mathrm{ml}$,
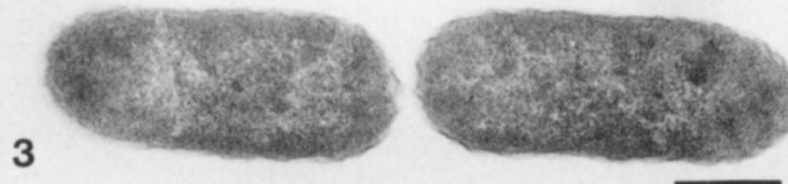

Fig. 3. Thin-section electronmicrograph of E. coli strain ECSA 1 showing the double-membrane cell wall, and cytoplasm containing ribosomes and nuclear material. Bar $=0.5 \mu \mathrm{m}$.

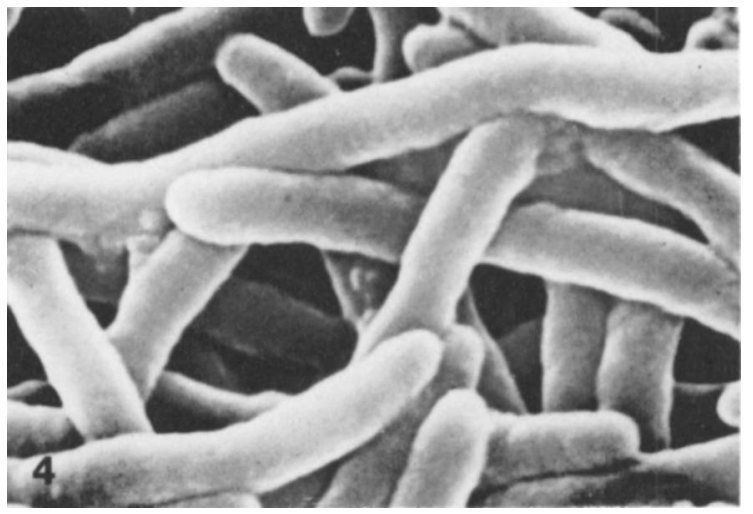

Fig. 4. Scanning electronmicrograph of $E$. coli strain ECSA 1 exposed to norfloxacin $10 \mu \mathrm{g} / \mathrm{ml}$ for $0.5 \mathrm{~h}$, showing filaments with relatively smooth cell walls. Bar $=0.5 \mu \mathrm{m}$.

filamentation occurred within 30 min (fig. 4). During the following hour of drug exposure, membrane-bound intracellular vacuoles containing strands of nuclear material developed at the ends of the cells (figs. 5 and 6). The vacuoles continued to increase in size and the strand-like material dispersed. At this stage the bacteria had an appearance similar to that of plasmolysed cells with apparent cytoplasmic shrinkage.

Cell elongation appeared to continue until the vacuoles were fully formed. Multiple smaller vacuoles, situated along the inner cytoplasmic membrane, and membranous vesicles on the outer membrane of the cell wall (fig. 7) were also present after exposure to the drugs for $30 \mathrm{~min}$. Some swollen bacteria were also observed. Breaks subsequently occurred in the cell walls of bacteria containing the terminal vacuoles (figs. 8 and 9),

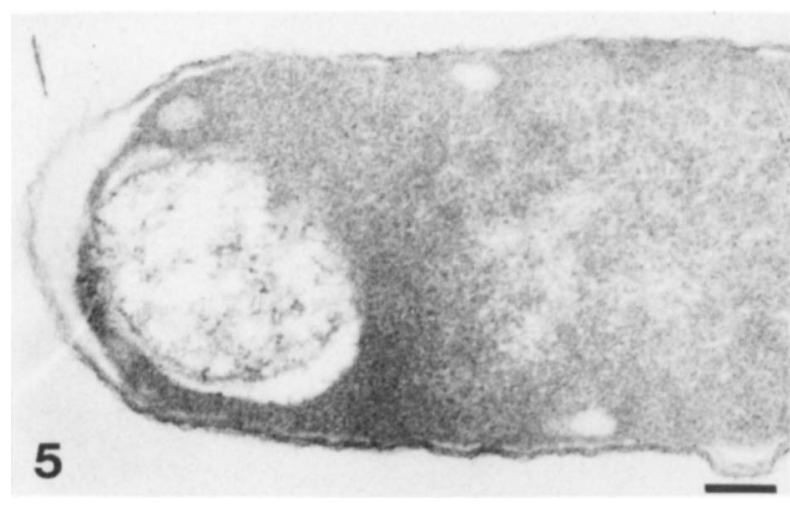

Fig. 5. Thin-section electronmicrograph of $E$. coli strain ECSA 1 exposed to ciprofloxacin $50 \mu \mathrm{g} / \mathrm{ml}$ for $0.5 \mathrm{~h}$ showing terminal lesions with the formation of membrane-bound vacuoles containing nuclear strands. Bar $=0.2 \mu \mathrm{m}$. 


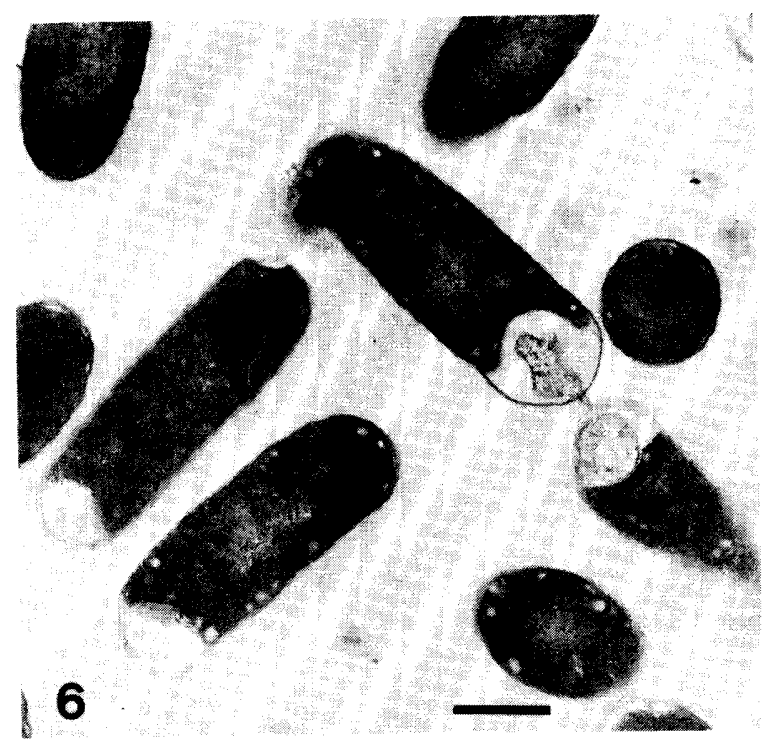

Fig. 6. Thin-section electronmicrograph of $E$. coli strain ECSA 1 exposed to ciprofloxacin $100 \mu \mathrm{g} / \mathrm{ml}$ for $0.5 \mathrm{~h}$. Terminal lesions with numerous smaller vacuoles along the inner membrane are present. Lysis of cells of normal length is demonstrated. Bar = $0.5 \mu \mathrm{m}$.

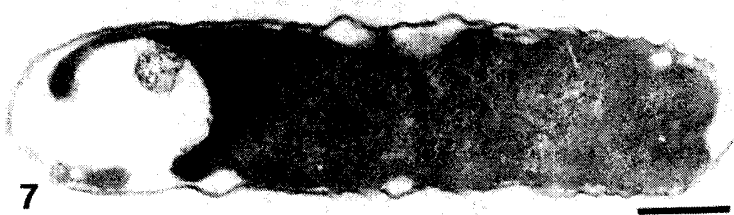

Fig. 7. Thin-section electronmicrograph of E. coli strain ECSA 1 exposed to ciprofloxacin $50 \mu \mathrm{g} / \mathrm{ml}$ for $1 \mathrm{~h}$. Terminal lesions communicating with lateral vesicles are shown. Bar $=0.2 \mu \mathrm{m}$.

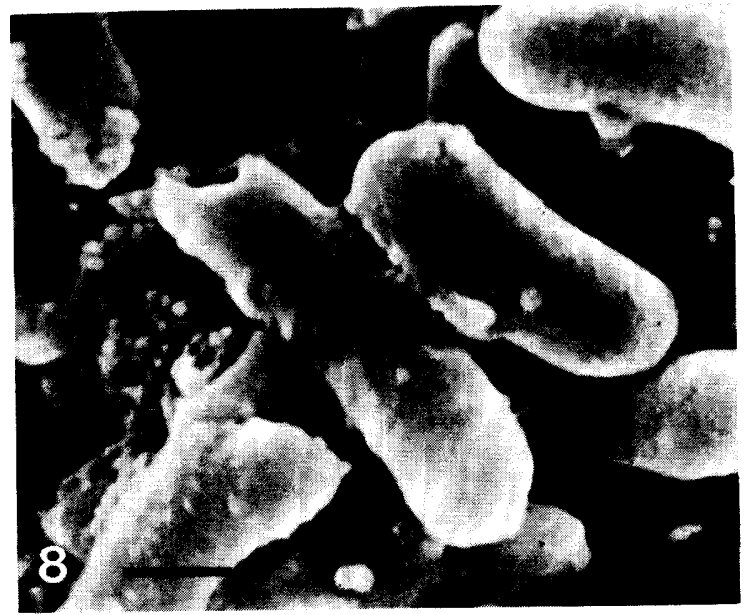

Fig. 8. Scanning electronmicrograph of $E$. coli strain ECSA 1 exposed to ciprofloxacin $100 \mu \mathrm{g} / \mathrm{ml}$ for $1 \mathrm{~h}$ showing breakage of cell wall at terminal end. $\mathrm{Bar}=0.5 \mu \mathrm{m}$.

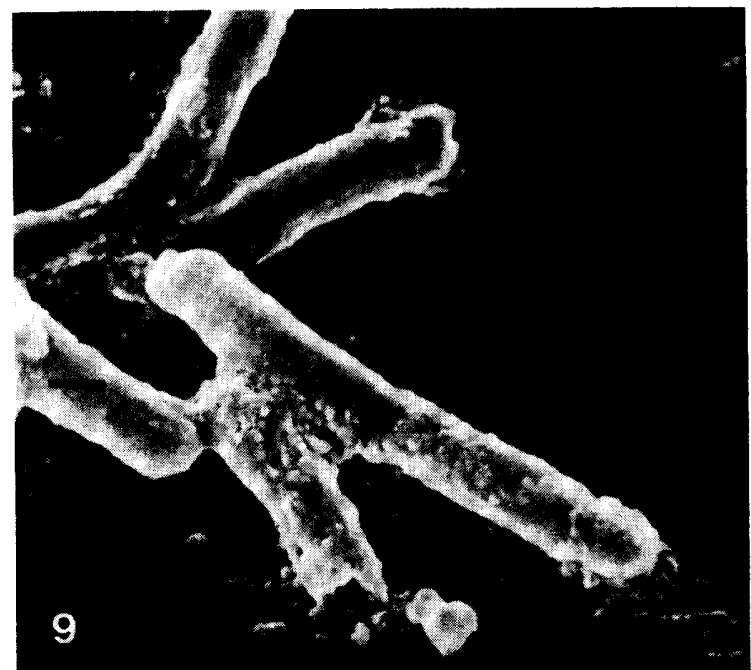

Fig. 9. Scanning electronmicrograph of $E$. coli strain ECSA 1 exposed to norfloxacin $10 \mu \mathrm{g} / \mathrm{ml}$ for $6 \mathrm{~h}$ showing lysed filaments with breaks in their terminal cell wall and vesicles on the outer membrane. Bar $=0.5 \mu \mathrm{m}$.

resulting in the extrusion of cytoplasmic contents. Affected cells characteristically exhibited large breaks in their cell walls at their terminal ends (figs. 8 and 9).

Some lysis was observed in cells of normal length within $30 \mathrm{~min}$ of exposure to a drug and this was particularly evident in cultures exposed to ciprofloxacin and norfloxacin at concentrations of

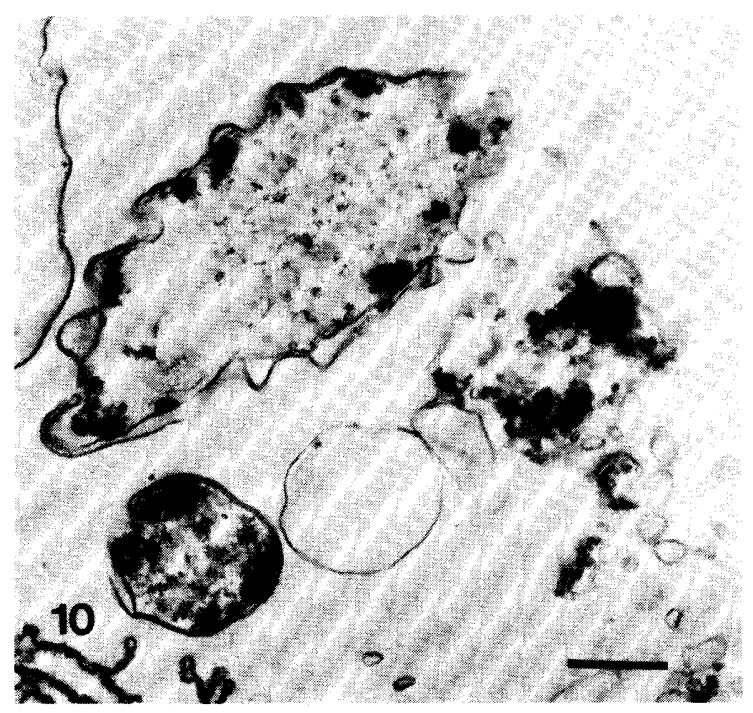

Fig. 10. Thin-section electronmicrograph of $E$. coli strain ECSA 1 exposed to ciprofloxacin $100 \mu \mathrm{g} / \mathrm{ml}$ for $5 \mathrm{~h}$. Numerous lysed cells with a restricted number of breaks in their walls are present. Bar $=0.5 \mu \mathrm{m}$. 


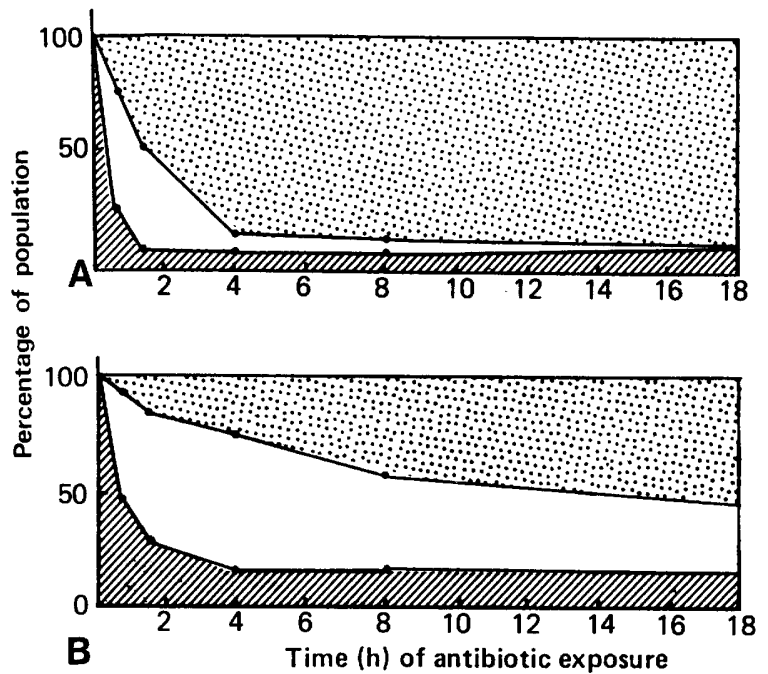

Fig. 11. Morphological response of E. coli strain ECSA 1 to norfloxacin: A, $100 \mu \mathrm{g} / \mathrm{ml} ; \mathrm{B}, 0.5 \mu \mathrm{g} / \mathrm{ml}$. 四=Normal cells; $\square=$ filaments; : $=$ lysed cells.

$100 \mu \mathrm{g} / \mathrm{ml}$. At lower concentrations lysis typically followed filamentation and swelling. Lysis continued during the first $2 \mathrm{~h}$ of drug exposure and many cell fragments were observed in the treated cultures (fig. 10). The proportion of bacteria undergoing filamentation or lysis after exposure to low and high concentrations of norfloxacin is shown in

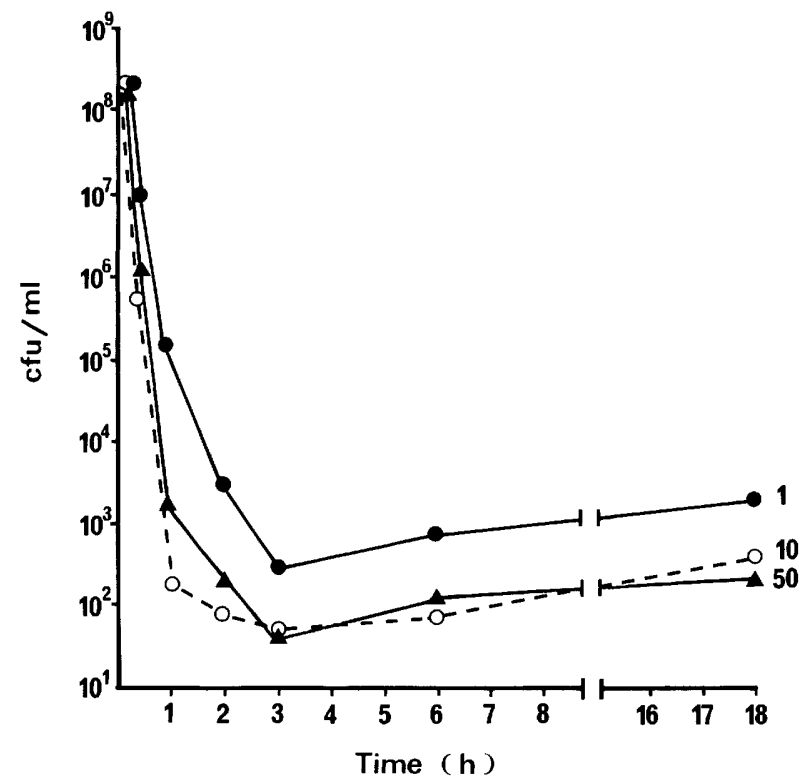

Fig. 12. Viable counts of $E$. coli strain ECSA 1 exposed to ciprofloxacin 1,10 or $50 \mu \mathrm{g} / \mathrm{ml}$.

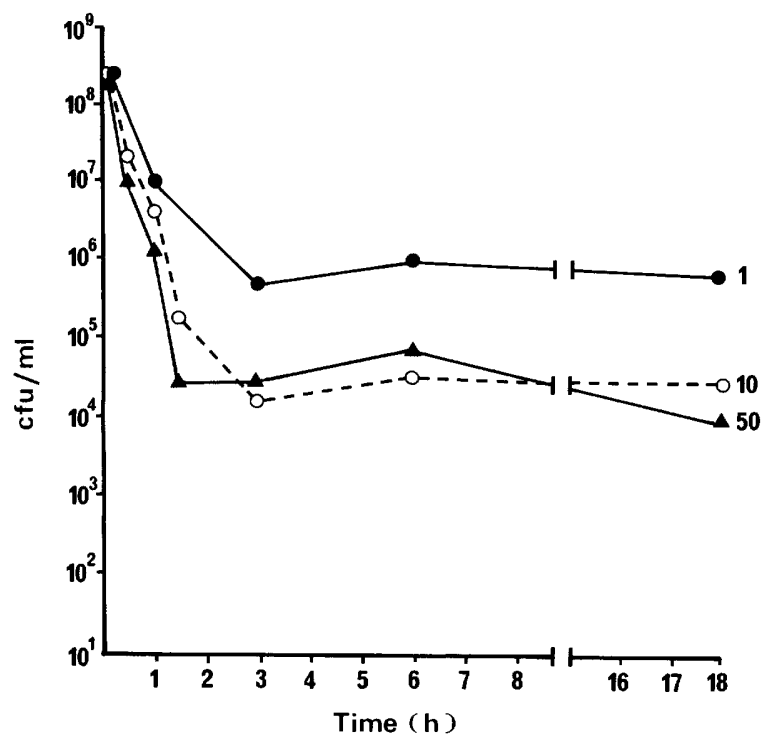

Fig. 13. Viable counts of $E$. coli strain $23 T$ exposed to norfloxacin 1,10 or $50 \mu \mathrm{g} / \mathrm{ml}$.

fig. 11. Similar results were obtained with bacteria exposed to ciprofloxacin.

When the nalidixic acid-resistant strain of $E$. coli was exposed to either ciprofloxacin or norfloxacin, less filamentation and lysis was observed and more cells appeared unaffected. However, the morphological changes accompanying lysis, i.e., the formation of intracellular and terminal vacuoles, were similar in both strains.

\section{Viable counts}

The results of viable counting confirmed that cell death occurred within $30 \mathrm{~min}$ of exposure to inhibitory concentrations of either drug. The rate of the lethal effect increased as the drug concentration was raised (fig. 12). In comparison, a much reduced bactericidal effect was observed with the nalidixic acid-resistant strain, a finding in keeping with the turbidimetric results (fig. 13).

\section{Discussion}

Ciprofloxacin and norfloxacin are structurally closely related and, although ciprofloxacin is the more active, the two compounds probably act in a similar manner by interfering with DNA supercoiling and activation of the SOS response (Little and Mount, 1982; Smith, 1984). However, the bactericidal activity of ciprofloxacin is not as readily reversed by inhibition of RNA or protein synthesis as that of norfloxacin; this has been taken to suggest 
that ciprofloxacin may possess an additional bactericidal mechanism not shared by norfloxacin (Smith, 1984). The present results revealed no qualitative differences in response to the two compounds over the concentration ranges tested. In both cases the overall response of $E$. coli - filamentation, vacuole formation and lysis - was similar. Moreover, similar morphological changes were observed in a nalidixic acid-resistant strain of $E$. coli although the changes occurred at much higher drug concentrations.

Filamentation probably occurs as a non-specific response to interference with DNA synthesis. For example, many physical and chemical agents induce filamentation in rod-shaped bacteria (Slater and Schaechter, 1974).It has also been recognised for many years that failure of gram-negative bacilli to form division septa follows damage to DNA caused by UV irradiation, thymine starvation (in thyminerequiring mutants) and nalidixic acid (Walker and Pardee, 1968).

The most striking feature of the response of $E$. coli to ciprofloxacin and norfloxacin revealed by the present study was the formation of membranebound terminal intracellular vacuoles, initially associated with strand-like nuclear material. Similar polar vacuoles have been independently described by Dougherty and Saukkonen (1985) in $E$. coli strain $\mathrm{B} / \mathrm{r}$ exposed to nalidixic acid, but, as these authors point out, interpretation of division defects in $E$. coli strain $\mathrm{B} / \mathrm{r}$ is difficult because that is a lon $^{-}$ mutant strain which also carries a lon suppressor. Our results confirm that polar vacuolation occurs in wild-type strains of $E$. coli. The findings additionally suggest that the vacuoles develop within the cells as filamentation progresses; the cells eventually collapse at the poles and lysis occurs by extrusion of the cytoplasmic contents through breaks in the cell wall. However, some bacteria lysed before filamentation. This was particularly marked at high concentrations of drug.

The paradoxical observation that bacteria continue to elongate (and hence to grow) while the viable count falls (Smith, 1984) appears to occur for two reasons: (i) a proportion of the population dies before undergoing filamentation; (ii) some filamentous cells incur extensive membrane damage so that, although growth continues for a short period, they effectively reach a point of 'no return' after which they are unable to recover from drug effects to form colonies. This effect is likely to be reinforced by the tight binding of quinolones to the cell, which necessitates washing of the antibiotic-damaged bacteria before viable counting - a process which is likely to amplify artificially the apparent bactericidal effect.

We are grateful to Bayer UK Ltd and Merck, Sharp and Dohme Ltd for financial help towards the cost of this study.

\section{REFERENCES}

Dougherty T J, Saukkonen J J 1985 Membrane permeability changes associated with DNA gyrase inhibitors in Escherichia coli. Antimicrobial Agents and Chemotherapy 28:200206.

Elliott T S J, Greenwood D 1983 The response of Pseudomonas aeruginosa to azlocillin, ticarcillin and cefsulodin. Journal of Medical Microbiology 16:351-362.

Greenwood D, O'Grady F 1973 Comparison of the responses of Escherichia coli and Proteus mirabilis to seven $\beta$-lactam antibiotics. Journal of Infectious Diseases 128:211-222.

Greenwood D, O'Grady F 1978 The response of Escherichia coli to nalidixic acid. Chemotherapy 24:249-258.

Greenwood D, Baxter S, Cowlishaw W A, Eley A, Slater G J $1984 a$ Antibacterial activity of ciprofloxacin in conventional tests and in a model of bacterial cystitis. European Journal of Clinical Microbiology 3:351-354.

Greenwood D, Osman M, Goodwin J, Cowlishaw W A, Slack R $1984 b$ Norfloxacin: activity against urinary tract pathogens and factors influencing the emergence of resistance. Journal of Antimicrobial Chemotherapy 13:315-323.

Little J W, Mount D W 1982 The SOS regulatory system of Escherichia coli. Cell 29:11-22.

Mackintosh I P, O'Grady F, Greenwood D, Watson B W, Crichton T C, Piper R, Ferrer A 1973 A twelve channel bacterial growth monitoring system. Biomedical Engineering 8:514-515, and 526 .

Newsom S W B, Matthews J, Amphlett M, Warren R E 1982 Norfloxacin and the antibacterial $\gamma$-pyridone $\beta$ carboxylic acids. Journal of Antimicrobial Chemotherapy 10:25-30.

Slater M, Schaechter M 1974 Control of cell division in bacteria. Bacteriological Reviews 38:199-221.

Smith J T 1984 Awakening the slumbering potential of the 4quinolone antibacterials. Pharmaceutical Journal 233:299305.

Walker J R, Pardee A B 1968 Evidence for a relationship between deoxyribonucleic acid metabolism and septum formation in Escherichia coli. Journal of Bacteriology 95:123-131.

Wise R, Andrews J M, Edwards L J 1983 In vitro activity of Bay 09867, a new quinolone derivative, compared with those of other antimicrobial agents. Antimicrobial Agents and Chemotherapy 23:559-564. 